\title{
A CRIANÇA DE/NA RUA TEM FAMÍLIA: UMA FAMÍLIA EM CRISE*
}

\section{THE STREET CHILDREN HAVE A FAMILY: A FAMILY IN CRISIS}

Moneda Oliveira Ribeiro ${ }^{1}$

RIBEIRO, MO. A criança de/na rua tem familia: uma familia em cnse. Rev. Bras. Cresc. Desenv Hum., São Paulo, 11(1), 2001.

Resumo: O artigo apresenta parte dos dados da tese da autora referente à trajetória da vida de um grupo de crianças de na rua, em idade escolar, que frequentavam dois refúgios públicos da cidade de São Pauío. Os dados, coletados por meio de entrevistas, foram analisados segundo as teorias da Representação Social e da Análise de Conteúdo conforme BARDIN e MINAYO. As categorias temáticas destacadas do discurso transcrito foram agrupadas em experiências sigmficativas para as criamças, entre as quais "a família". A sintese das categorias analisadas eviden ciou que a violência permeia a vida dessas crianças, resultamdo em experiências que restringem seu pleno desenvolvimento A autora identifica que as crianças fogem de casa quando sua familia fracassa em sua função de provedora de proteção e abeto, e conclui que a solução do problema depende da implementação de Politicas Sociais e de Saúde, sobretudo à criançafamília em situação de risco.

Palavras-chave: criança de na nua; familia; violência; saúde escolar.

\section{INTRODUÇÃO}

Está equivocado quem pensa que a criança de rua está nessa condição porque não tem família. Todas elas têm. O problema reside no fato de que, em geral, sua família está em crise, sem estrutura para resolver seus próprios problemas. Isso nào significa que, necessariamertte, seus pais sejam incompetentes para criar seus filhos. A questão ultrapassa o limite da sensatez. A família da criança em situaçào de rua compõe uma parcela da sociedade que não recebe apoio do Estado porque este não implementa políticas sociais e de saúde efetiva para dar o suporte que as famílias mais carentes necessitam para exercer seu papel de pro- vedores do desenvolvimento de seus filhos. $\mathrm{O}$ descaso do Estado, contudo, nào exclui a parcela de responsabilidade dos pais na criação de seus filhos, mas também não se pode julgá-los como os únicos responsáveis pelo elevado número de crianças que estão vivendo da rua.

Por essa razão, qualquer profissional que se dispõe a incorporar-se na luta pela defesa dessa categoria de crianças, precisa levar em conta que a família delas também precisa de ajuda. Do contrário, todo esforço para estimular a criança a retomar ao seu convívio familiar será em vào. Essa questào ficou evidente no estudo que desenvolvi com um grupo de crianças (de 8 e 12 anos) que viveram na rua.

\footnotetext{
* Parte da Tese de Doutorado apresentada à Escola de Enfermagem da Rscola de Enfermagem da USP em 10/12/99. Titulo: A criança de/na rua em idade escolar: um olhar sobre sua trajetóna de vida.

1 Enfermeira Profa. Dra. do Departamentç de Enfermagem Matemo-lnfantil e Psiquiátrica da Escola de Enfermagem da I Uiversidade de SãoPaulo - Av. Dr. Eneas de Caralho Aguiar - 419 - Cerqueira Cesar - São Paulo E-mail moneda@usp.br
} 
O objetivo do trabalho consistiu em identificar a representação social sobre a trajetória de vida (especialmente sobre as situações de desatendimento à saúde) de um grupo de crianças (em idade escolar) que viviam na e da rua. O intuito foi conhecer a criança em situação de rua para que o profissional de saúde possa consolidar propostas alternativas de assistência e de ensino com vistas à promoção do desenvolvimento desse grupo específico. Além disso, pretendi sensibilizá-lo para o fato de que a atenção a essa categoria transcende o âmbito da assistência à saúde, consiste também em exercício da cidadania.

No referido estudo foi possível apreender que o ponto de partida dos relatos sobre a trajetória de vida das crianças começa com as fugas de casa. Elas vão para as ruas e estabelecem relações muito significativas (positivas ou negativas) com os amigos, as drogas e a polícia. Quando necessitam suprir suas necessidades básicas, recorrem aos abrigos. Assim, esse percurso é caracterizado por um movimento de ir e vir: das ruas retornam para casa ou para os abrigos, e destes fogem novamente, seguindo um caminho sem um destino bem definido e sem perspectivas de um futuro vindouro.

\section{ESTRATÉGIA METODOLÓGICA}

Para atingir o objetivo proposto, selecionei crianças em idade escolar (de 7 a 12 anos) que viviam na cidade de São Paulo e utilizavam a rua como meio de sobrevivência e espaço para seu desenvolvimento. Considerei que a criança nessa faixa etária tem capacidade para comunicar-se através da linguagem e, desta forma, emitir sua representação do mundo e a compreensão que tem da realidade que a cerca. Por essa razão, a entrevista semi-estruturada foi a estratégia escolhida para obter os dados que permitissem identificar sua representação em relação a si mesma, a sua família, ao meio onde vive e aos demais enfoques por ela revelados. Os dados, então, foram coletados através de entrevistas realizadas individualmente com catorze crianças que freqüentavam dois refúgios públicos da cidade de São Paulo: um abrigo vinculado a uma instituição estadual e um albergue da prefeitura administrado por uma entidade não governamental.

A autorização para realizar as entrevistas com as crianças que tinham história de vivência na rua e atingiam os requisites pretendidos ocorreu em duas instâncias: junto aos responsáveis pelos refúgios (guardiãs legais) e através das próprias crianças. Estes foram devidamente esclarecidos sobre: o objetivo da pesquisa, o procedi- mento das entrevistas, a utilização das informações das crianças e o caráter sigiloso do estudo. Assim, manifestaram o consentimento informado conforme preconizado pelos princípios éticos das pesquisas com seres humanos (BRASIL/ 1996).

\section{A coleta de dados}

As entrevistas iniciavam com uma pergunta aberta como "conte-me sobre sua experiência na rua" ou "como você se sente estando na rua" e transcorriam com algumas intervenções com o intuito de estimular as crianças a continuarem falando. Assim, as entrevistas evoluíam como um diálogo espontâneo. Em geral, as crianças eram prolixas, somente algumas necessitavam de estímulo para se expressarem. Nesse caso, eu as estimulava com perguntas que surgiam do próprio contexto enfocado pela criança, buscando esclarecer pontos obscuros ou buscando obter mais informações a respeito do tema em vigor. Além disso, tive a preocupação de usar uma linguagem simples e concreta, compatível com a fase do desenvolvimento das crianças. Estava atenta para usar somente os termos triviais empregados por elas. Evitou-se, assim, todo tipo de conceitos cujas abstraçôes ultrapassassem a compreensão delas.

\section{A sistematização e análise dos dados}

O instrumento principal utilizado para obter a representação social do indivíduo é seu discurso. Este, expresso através da linguagem, possibilita sua decomposição e reconstrução tornando possível a compreensão do conteúdo da mensagem. A linguagem é um recurso que viabiliza o intercâmbio social e, como resultado deste, o indivíduo constrói sua representação social.

Uma vez que a linguagem revela o pensamento, o registro do discurso das crianças decorrentes das entrevistas com a autora foi o meio pelo qual se obteve a versão delas em relação ao objetivo do estudo. Assim, os dados foram registrados por meio de gravação e transcritos na íntegra. $\mathrm{Na}$ apresentação de partes das entrevistas, "P" refere-se ao pesquisador e as demais letras referemse às iniciais dos nomes fictícios atribuidos às crianças.

A "sistematização dos dados empíricos” (do texto discursivo) foi organizado conforme as principais normas de validade da "análise temática”, uma das técnicas de Análise de Conteúdo, referidas por MINAYO (1993). Assim, os dados foram sistematizados de modo a manter o conteúdo do pensamento e o significado da mensagem manifestada pela criança. A "análise dos dados” foi realizada segundo as perspectivas teó- 
ricas da Representação Social conforme preconizado por BARDIN (1979), JOVCHELOVITCH (1998), SPINK (1993), entre outros.

Segundo esses autores, a representação é um ato do pensamento resultante da relação do sujeito com o objeto (seja este coisa, pessoa, acontecimento ou idéia). É através dela que se torna possível captar a realidade subjetiva do indivíduo em relação à realidade objetiva. É nessa perspectiva que se trouxe à tona a visão da criança de/na rua em relação ao objetivo proposto. Como o estudo foi pautado em um enfoque psicossocial, os referenciais teóricos que nortearam a análise dos dados foram selecionados tendo em vista os efeitos da realidade sobre a representação social do indivíduo. Por isso, a abordagem teórica foi pautada em autores que consideram a determinação social na visão de mundo do indivíduo que, por sua vez, influencia suas condutas nas relações sociais. A análise dos dados foi fundamentada, também, segundo autores que realizaram estudos relacionados ao desenvolvimento infantil numa abordagem humanista e histórica.

Em suma, os temas significativos destacados dos dados empíricos foram agrupados em categorias. A interpretação dos dados foi realizada em função dos temas emergentes que representaram a reconstrução das dificuldades enfrentadas por elas em seu processo de desenvolvimento. Assim, uma das unidades temáticas que surgiu da análise do discurso das crianças entrevistadas originou a categoria "família”.

\section{APRESENTAÇÃO DOS DADOS}

A família foi um tema comentado por todas as crianças entrevistadas. Algumas falavam pouco a respeito, mas todas contaram o motivo que as levaram a fugir de casa. As razões apresentadas foram devido à "ausência da mãe”, às “agressões dos genitores” e à "miséria e desagregação familiar”. De modo geral, as crianças referem uma história de crise na estrutura familiar que as levaram buscar a fuga como alternativa para livrarem-se do tratamento austero, negligente ou agressivo de seus genitores ou responsáveis. As crianças relataram várias fugas de casa porque as autoridades as levavam de volta à suas famílias quando encontradas na rua. Mas, em casa, enfrentavam os mesmos problemas que motivaram a fuga e, assim, retornavam à rua. Os relatos das crianças, apresentados adiante, elucidam os motivos das fugas.

\section{A ausência materna}

A ausência da mãe, seja devido à sua morte, abandono ou separação dos pais, foi uma das causas principais relatadas como geradoras de crise na vida de algumas crianças. Essa perda da mãe tornava-se um problema quando a figura substituta (madrasta, avó, tia ou pai) não supria as necessidades da criança, ou quarido o responsável a tratava com descaso e agressividade. Para essas crianças, o mito da madrasta má dos contos-defada é realidade.

\begin{abstract}
J. Minha mãe morreu, fui pra casa da minha madrasta. Ai fui pra rua. Aí eu vim pra cá agora (no abrigo). Não quero voltar pra casa. O SOS me levou pra casa mais de cinco vezes e eu fugia de novo.

\section{P. O que acontecia?}

J. Minha mãe (madrasta) me batia. Ela me batia muito, me fazia de empregada, não me deixava ficar dentro da minha casa. Aí eu fugia, fugia. Eu não queria voltar mais pra casa, nem vou voltar.
\end{abstract}

Uma das crianças manifestou essa situação de conflito com a madrasta. Ao ser questionada sobre o que significava "saúde" para ela, explicou o termo relacionando-o ao bem-estar familiar, dando um sentido de "acolhimento" ao expressar que saúde é ser "cuidada" pelos pais. A vida saudável que ela tinha deixou de ser realidade com a ausência da mãe, resultando em sua fuga de casa.

\section{V. (Saúde) é quando a gente está melhor, se alimentando bem. Quando a gente está com os nossos pais, as nossas mães. Quando eles estão cuidando da gente direito, quando eles alimentam a gente. \\ P. Isso acontece com você? \\ $V$. Acontece, mas só que minha mãe morreu... ai meu pai... aí minha madrasta começou a me bater, aí eu fugi de casa. \\ P. E você foi prá onde? \\ V. Eu fui prá rua, aí as policias me pegaram. Aí eu fui pro SOS e depois vim prá cá ( $p$ / o abrigo).}

Essa criança representava a figura materna, apesar de ausente, como referência das suas experiências, fossem estas boas ou más. Tudo de bom relacionava-se à presença da mãe, e tudo de mal relacionava-se à sua ausência. A figura paterna surge como "cúmplice" da madrasta, não atenuando a sensação de desamparo da criança.

P. O que de ruim lhe aconteceu que você nunca esqueceu?

V. Ouando minha mãe morreu. Faz um ano. 
P. Você lembra dela?

V. Lembro. (Estava cabisbaixa)

P. Sente saudade?

V. (Não respondeu, continuava cabisbaixa).

P. O que de melhor já lhe aconteceu? V. Quando minha mãe fez festa pra mim, bolinho. Ela nunca esqueceu do meu aniversário, mas meu pai não faz aniversário pra mim por causa da minha madrasta. Ela não gosta que ele faz aniversário pra mim. (Pausa)

P. Conte-me um sonho que você teve. $V$. Tive um sonho chato depois que minha mãe morreu. Ela aparecia e desaparecia. (Batia o fio do microfone agitadamente). Ai ela foi no banheiro e estava nascendo chifre nela e ela saiu correndo.

P. Voceficou assustada!

V. (Assentiu). Eu não conseguia acordar.

P. Então, isso foi um pesadelo.

V. Aí o homem começava a dar risada e não parava de rir Ai meu pai deixou eu sozinha no matão. (...) Eu não conseguia acordar, tia. Só os sonhos bons que eu acordo.

P. (...) Você lembra de um sonho bom? V. Lembro, espera um pouco (ficou pensando). Foi quando eu sonhei que minha mãe comprou um apartamento. Ai ela não precisava de pagar. Tinha piscina e comecei a nadar. Aí só sonhei um pouquinho, eu acordei, não consegui ficar dormindo. Mas eu queria sonhar até à noite.

No caso de uma outra criança, a tia "assumiu” seus cuidados mas não supria as necessidades de afeto conforme suas expectativas. Apesar da criança não tecer comentários a respeito de seu pai, em um momento da entrevista deixou evidente que ele não teve bom desempenho.

P. Como você se sente estando na rua?

T. É um pouco bom, um pouco ruim. Nunca é bom ficar na rua, orque a gente não tem o carinho de uma mãe. (...) Quando minha mãe morreu, eu tinha um ano e três meses. Ai, meu pai não tinha condições de me criar, então ele deu eu pra minha tia. Eu sou filha da minha tia, agora. (...), a gente pode até gostar da rua, mas chega uma hora que a gente se enche. Mas, a gente não se esquece da rua, dos nossos amigos, porque um dia... se eu voltar para minha casa, eu não vou falar com ninguém, eu não vou ter amigos. E na rua eu tenho muitos amigos.

P. Na sua casa nocê não tinha amigos? T. Não. Não podia sair para brincar. P. Sua tia não deixava?

T. Não. Ela não deixava sair pra rua. Aí depois ela mandou eu morar com o meu pai, ai eu peguei e fugi e vim prá cá pra rua.
Em um dos casos, a criança saiu de casa por uma combinação entre o estimulo de seus amigos e o tratamento recebido por sua madrasta. A entrevista feita com ela ajudou-a a expressar seus sentimentos e a encorajá-la a tomar uma atitude, a de voltar para casa de sua avó. A criança parecia estar sofrendo calada, não compartilhava sua dor e suas dúvidas. Após a entrevista, foi encaminhada para casa e, se não houvesse essa oportunidade, talvez ainda estivesse na rua.

P. O que fez você vir prá rua?

C. Eu vim por causa eu fui no embalo dos outros. (...) Eu fui no embalo dos outros e me ferrei. E até hoje eu tô aqui querendo ir pra casa, sem poder... sem poder me movimentar, brincar bem.

P. Voce tem mãe?

C. Tenho mãe, mas ela não mora comigo, eu moro com a minha avó.

P. Então, você saiu da casa da sua avó. C. É. Minha avó, a essas horas, tá preocupada comigo. Eu não queria que nenhuma mãe desses moleque (referia-se aos meninos do albergue) tivesse sofrendo. Mesmo que fizesse mal pro filho, mas é mãe, é mãe, quantas vezes eu não sofri com a minha mãe, e tô aí hoje querendo voltar com ela, querendo ficar em casa. Porque essa vida é ruim, você passa frio, fome, desespero. Uma hora você fica louco.

P. Você gostaria de ver a sua avó? C. Eu gostaria. Minha avó nunca me catou pra me bater assim prá me tirar sangue de mim, pra me espancar.

P. Sua mãe te batia?

C. Nem minha mãe, ninguém da minha família. Única pessoa que chegou a tirar sangue do meu nariz foi minha madrasta.

P. Você morava com a sua madrasta? C. Morava. Eu fugi, ai eu voltei a morar com a minha avó. Eu fugi de novo... ai até hoje eu tô aqui. Acho que faz uns cinco ou dez dias que eu fugi de casa.

P. Como você pensa em voltar prá casa?

C. Não sei, eu acho que vou ficar rodando minha casa, se minha avó me vê, de repente ela me chama e fala que não vai me bater.

P. Você tem medo que ela bata em você? C. Tenho.

P. Por isso que você não voltou até agora? C. É. (Pausa)

P. E se você for junto com um adulto? $C$ É, pode até dar certo. 
P. Você quer que eu peça pra alguém daqui encaminhar você? (Pausa) Eu não vou fazer isso se você não me pedir. (Pausa) Você gostaria?

C. Gostaria. (Chorando) Eu vou prá casa sim porque eu não gosto de ficar passando frio $e$ de ninguém me judiando, não gosto de ver ninguém me judiando. não é pra sofrer.

P. Lógico. Criança tem bom coração, é boa,

C. (Ainda chorando) Eu queria que ninguém, nenhuma criança f casse nesse mundo ai passando frio. Se eu fosse Deus, eu tirava todas as crianças e levava pão meu céu. Transformava elas em lindas, lindas e limpas, sem passar fome. (Chorava bastante)

\section{Agressões dos genitores}

Algumas crianças fugiram de casa porque os próprios pais legitímos as maltratavam. Em alguns casos, a mãe não conseguia proteger o filho porque o pai era violento com ela e com a criança. Surgiram casos em que a mãe morreu, ficando a criança aos cuidados de um pai agressivo. Mas também houve relatos de crianças cujas mães eram quem as maltratavam. As crianças que sofreram maus-tratos desde muito pequenas estão em abrigos há muito tempo, sendo caracterizadas como crianças institucionalizadas, sem perspectiva de retorno a um convívio familiar. No caso a seguir, ambos os pais eram agressivos com a criança.

\author{
P. Você recebe visita? \\ M. Não. \\ P. Você tem mãe, pai? \\ M. Tenho (pausa). \\ P. Eles vêm aqui? \\ M. Acenou negando (Respondeu cabisbaixo). \\ P. Como vocêfoi pró rua? \\ M. Ah, minha mãe estava me batendo demais. \\ Eu fugi.
}

P. E o seu pai? Também batia em você?

M. Também (Continuava cabisbaixo).

Em outro caso, a criança conta que a mãe morreu e o pai tornou-se alcoólatra e agressivo.

\section{P. E a sua mãe?}

W. Morreu quando eu era pequeno, eu nem conheci ela. Quando minha mãe morreu, meu pai começou a beber pinga. A mulher do lado ligou pró Juizado de Menor. Ai me pegaram, me mandaram pró J.M. e depois pró abrigo. Me pegaram de dentro de casa.

P. Então, você sempre ficou em abrigo. W. É.
P. Seu pai vem te visitar?

W. Ele nem sabe que eu tô aqui.

Adiante, as crianças relatam que seus pais eram agressivos com elas e com suas mães.

P. Porque você foi pra rua?

S. Meu pai me batia, me batia de fio, aí eu fugi de casa.

P. E sua mãe? Você tem mãe?

S. Tenho. Minha mãe não podia fazer nada, meu pai também batia nela. Aí eu fugi de casa.

P. Efaz tempo que você não vê sua mãe? S. Faz. (Pausa)... P. Você tem irmãos?

S. Tenho oito, seis em casa e dois na rua. Nunca mais eu vi meus irmãos, tia.

\section{Outro relato:}

\begin{abstract}
A. Minha vida é rua, por causa que eu não gosto do meu pai, ele fica bebendo muita cachaça e fica batendo em mim e na minha mãe. Agora, só tá eu e meu pai. Minha mãe morreu de ataque do coração. Levaram ela pro Pronto Socorro mas não deu certo. Aí fizeram um caixão e levaram ela lá no cemitério. Enterraram, aí meu irmão começou a brigar com meu pai, meu pai bateu nele e ele fugiu de casa. Aí eu fugi também. Eu não gosto de ficar com meu pai porque ele bebe muito e fica me batendo, todos dia.
\end{abstract}

Houve um caso em que, segundo a criança, sua mãe era agressiva. A criança expressava hostilidade clara com todos os membros da família. Guardava consigo muito rancor e mostravase determinada a romper laços com a família, apresentando-se disposta a eliminar todos os obstáculos que impeçam seu propósito:

E. Eu ficava em casa, bagunçava. Na escola, bagunçava. Aí minha mãe começou a me bater, me batia, batia. Meu irmão fuxicava muito de mim. Aí minha mãe me batia, me batia. Aí, quando minha mãe saia, nos fins de semana, eu batia no meu irmão, batia, batia. Minha avó ia lá, me batia de vez em quando. Meus irmãos me batia. Eu pegava coisas escondida, comia, comia. Aí minha mãe chegava do trabalho, me batia. Aí eu comecei a fugir. Os outros (a polícia) me pegava e me levava pra casa de novo. Eu fugia de novo. Comecei a fugir de casa, fugia, ia fugindo. Aí, um dia, eu catei um lugar (um abrigo) $e$ fiquei lá.

E. Se meu pai estivesse lá (em sua casa), ele ia ser preso. Porque ele ia bater na minha mãe, e eu ia ajudar ele.

P. Seu pai não está mais lá? E. Meu pai tá morto. 

batia?

P. Ouando ele estava vivo, sua mãe não te

E. Quando eu... crescia... tinha oito... dez... meu pai já tinha morto.

P. Você era pequeno quando ele morreu.

E. Eu não cheguei a conhecer nem um pouquinho dele.

P. Faz tempo que você não vê sua familia?

E. Eu não quero saber deles.

P. (...) Não tem vontade de ver ninguém?

E. Não. Nem minha mãe. Se eu ver minha mãe qualquer dia aqui, e se eu estiver com uma faca eu mato ela.

P. Você não gosta dela?

E. Odeio. Se eu tiver com uma faca, se eu tiver com alguma coisa de crime e se ela passar aqui eu mato ela. Eu posso ir pra Febem, posso ir pra qualquer lugar, mas que eu mato ela pra sair da minha vida, eu faço. Ela só vai com a cara dos meus irmão. Se não fosse minha avó, pra me pegar pra me criar, eu já estaria com outra pessoa. Quando eu era pequeno, ela ia me dar pra outra pessoa.

P. Voce tem algum irmão que você gosta? E. Só minha irmã.

P. Ela nunca veio aqui?

E. Se ela vem, eu vou pra outro lugar, não venho mais pra cá. Eu quero meter minha cara sozinho, eu vou ter minha família sozinho.

\section{A miséria e a desagregação familiar}

Houve crianças que, embora não revelassem claramente, deixavam implícito que a rua já fazia parte do seu dia-a-dia, como um "habitat habitual” em suas vidas. Ainda assim, usavam a expressão "fugir de casa" quando apresentavam o motivo para estarem longe de seus pais. Usavam essa expressão porque saíram de casa sem o consentimento dos pais, embora estes sabiam onde encontrá-las. Eventualmente, essas crianças voltavam espontaneamente para casa a fim de "fazer uma visita”, por estarem com saudade de sua família ou por estarem cansadas da rua. Nos relatos das crianças sobre sua história familiar revelavam fatos que evidenciavam um quadro de pobreza acentuada: pertenciam às famílias numerosas, desagregadas, com história de algum membro envolvido com a marginalidade.

Algumas crianças não fugiam propriamente de casa, mas da escola. A obrigatoriedade de estudar levavam-nas a “cabular às aulas” e, dessa forma, ficavam nas ruas. A princípio permaneciam aos arredores de casa e pouco a pouco iam se afastando.
P. Você não quer ficar na sua casa? K. Não.

P. O que acontece lá?

K. Nada. É que eu não gosto de ir pra escola.

P. Sua mãe quer que você vá pra escola?

K. É, mas eu não gosto. Eu gosto de estudar à tarde, não gosto de estudar de manhã.

P. Por isso que você saiu de casa? K. Assentiu com a cabeça.

P. Você não tem vontade de voltar pra casa? K. Tem vez que eu volto. Quando eu arrumo mais dinheiro, eu volto pra casa.

K. Quando eu estava na segunda série ainda, meu irmão saia por trás da escola. (...) Eu também estou de busca pressão, porque eu saí de casa, f...) nós saímos sem ordi.

P. Fale um pouquinho de sua família. K. Eu tenho nove irmão. Quatro está no orfanato e o resto está com a minha mãe. (...) Na minha casa não tem televisão, aí minha irmã assiste na casa dos outros.

\section{P. E você?}

K. Eu ia nas outras casas assistir televisão, chegava só de noite.

Algumas crianças relatavam sobre o envolvimento de algum membro da família com a delinqüência.

P. Quantos irmãos você tem ?

$V$. Somos em quatorze, eu estou no meio.

P. Onde eles estão?

V. Na minha casa. (Respondia cabisbaixa agitando o fio do microfone)

P. Só você está aqui!

V. Só eu. E mais dois que estão um na cadeia e outro na Febem. Um de 16 e outro de 17 que está na cadeia.

P. Elefez alguma coisa?

V. Ele roubou. Ele roubou laranja. (Riu e parou de agitar o fio).

P. Roubou laranja? Foi pra cadeia porque roubou laranja?

V. Não, prá Febem.

P. E o que está na cadeia?

V. O que está na cadeia roubou banco.

Era comum as crianças tecerem comentários a respeito de sua famílias que deixavam transparecer a situação de desagregação farniliar. 
P. Você morava com seu pai?

B. Com meu pai e com a minha madrasta. Minha mãe morava em Santos, meu irmão estava preso e minha outra irmã não sabia onde estava.

P. E seus irmãos, estão com quem agora?

B. Com meu pai e com minha madrasta.

P. Os menores, mas você tem irmãos maiores que você?

B. Tenho.

P. Eles estão aonde?

B. Estão tudo em Suzano, em Mogi.

P. O que é lá?

B. É a casa da minha tia Eu tenho duas irmãs que estão morando com a minha tia.

P. Com quem você gostaria de ficor se não for com a sua madrasta?

B. Com a minha tia.

P. Ela não pode ficar com você?

B. Ela pode, mas só que não conversou com ela ainda. Eu tenho outros irmãos (citou seis nomes). Tem... (citou mais três nomes).

\section{Outro caso:}

P. Você tem irmãos?

W. Tenho um que é adotado, o outro tá com a madrinha e outro tá preso.

As crianças em que a rua já fazia parte de seu cotidiano, como se fosse a extensão de sua casa e parte integrante de seu ambiente, não apresentavam queixa de nenhum membro da família, mas afastavam-se de casa por vários dias sem consentimento dos pais e sem aviso prévio.

P. Por que você saio de casa?

L. Por nada. Fugia por nada.

P. Não veio ninguém atrás de você?

L. Minha mãe já procurou eu, já fui pra casa.

Ia prá casa e fugia, ia pra casa e fugia.

Uma das crianças relatou que os conflitos em casa motivou sua fuga. Embora ela não fosse diretamente atingida por tais conflitos, não encontrava ambiente harmonioso em sua casa. de casa?

P. Como tudo começou. Como você saiu

H. Minha mãe perdeu a casa, por ordem do juiz. Daí a gente vinha pra cá, pra SP. Nós tava morando na casa de uns tios nosso. Daí eles vendeu a casa. Minha mãe conseguiu (ajuda para) construir uma casa. (...) Meu pai que é ex-marido da minha mãe, (...) não mora com minha mãe. Ela não se dá bem com ele, eles ficavam sempre brigando, e por isso eu sai...

P. Agora, ela está morando com seu padras-

to.

H. Meu padrasto. É, minha mãe também não se dá bem. A gente mora em casa, mas só que não se dá bem, tia.

\section{APRECIAÇÃO DOS DADOS}

Recapitulando os relatos das crianças referentes à ausência materna, às agressões dos genitores e à miséria e desagregação familiar, notei que havia um ponto em comum entre esses três requisitas que motivaram a fuga das crianças: a falta de uma mãe carinhosa, com qualidades pessoais e recursos materiais suficientes para a manutenção familiar parece ser a condição principal para a criança permanecer em casa.

Ao avaliar os relatos das crianças quanto à ausência da mãe, fica bem evidente que a mãe protetora era o alicerce de suas vidas. Salvo algumas exceções, tudo começou a desabar quando as crianças perderam, por algum motivo, o cuidado materno. Através de seus relatos, estava implícito que se uma outra pessoa (pai, madrasta, avó ou tia) assumisse com competência esse cuidado, as crianças conseguiriam suprir suas carências. Mas a falta de uma mãe substituta desencadeou um processo de destruição na vida das crianças que perderam sua mãe. Suas madrastas não conseguiram suprir suas necessidades de afeto, fracassando no papel de mãe substituta.

BOWLBY (1993) faz referência sobre como o binômio mãe-filho repercute no desenvolvimento da criança. Define os conceitos de "figura materna" e "mãe substituta" relacionandoos ao vínculo que a criança estabelece com ambas. Diz ele: "Por figura materna entende-se aquela pessoa para a qual a criança orienta, de acordo com preferências, seu comportamento de apego; por mãe substituia entende-se qualquer outra pessoa para a qual a criança está disposta, provisoriamente, a dirigir seu comportamento de apego.” (p. 23/v. 2).

O autor define o "comportamento de apego” como um forte sentimento decorrente da dependência da criança em relação à figura materna. "Nenhuma forma de comportamento é acompanhada por sentimento mais forte do que o comportamento de apego. As figuras para as quais ele é dirigido são amadas, e a chegada delas é saudada com alegria. Enquanto uma criança está 
na presença incontestada de uma figura principal de apego, ou a tem em seu alcance, sente-se segura e tranqüila. Uma ameaça de perda gera (na criança) ansiedade, e uma perda real, tristeza profunda, ambas as situações podem, além disso, despertar cólera, sentimento de raiva, ódio ou desprezo”. (p. 224/v. l).

Refere que a falta da figura materna, ou de sua substituta, traz sérias conseqüências futuras no desenvolvimento da criança. Ele explica que “a principal causa de uma personalidade instável e angustiada é a incerteza torturante quanto a se mostrarem as figuras de apego acessíveis e receptivas; verificamos haver também fortes razões para acreditar que o alicerce sobre o qual se constrói uma personalidade estável e autoconfiante é a certeza despreocupada de contar com a presença e o apoio das figuras de apego.” (p. 340/v. 2).

Segundo ROBERTSON (apud BOWLBY/ 1993), se a criança é retirada dos cuidados maternos ainda pequena (entre 18 e 24 meses), "quando está apegada de forma tão possessiva e apaixonada à mãe é, na verdade, como se seu mundo desabasse. Sua intensa necessidade da mãe permanece insatisfeita e a frustração e saudade pode torná-la desesperada de dor. (...) Ela não conhece a morte, mas apenas a ausência, e se a única pessoa que pode satisfazer sua necessidade imperativa está ausente, é como se estivesse morta, tão esmagador é o seu sentimento de perda”. (p. 6/v. 3).

Quando a perda da mãe ocorre por sua morte, o processo para superar seu sofrimento é muito penoso e de longa duração, diz BOWLBY (1993). “Acreditou-se, durante algum tempo, que a criança pequena logo esquecia a mãe e, portanto, superava seu sofrimento. Acreditava-se que o pesar na infancia tinha vida curta. Hoje, porém, uma observação mais profunda mostrou que não é assim. O desejo ardente do retorno da mãe persiste.” (p. 7/v. 3).

"Depois de uma fase de retraimento e apatia (...), a criança começa a buscar novas relações. A maneira pela qual estas se desenvolvem depende da situação em que ela se encontra. Desde que exista uma determinada figura materna com a qual possa se relacionar e que desempenhe para ela o papel de mãe carinhosa, com o tempo acabará por aceitá-la e tratá-la quase como se fosse sua própria mãe. Nas situações em que, ao contrário, a criança não tem ninguém com quem se relacionar, ou em que há uma sucessão de pessoas com as quais se estabelece um breve relacionamento, o resultado é diferente. Em geral, a criança torna-se cada vez mais egocêntrica e inclinada a estabelecer relações passageiras e superficiais com todos, sem exceção. Essa condição é um mau pressá- gio para seu desenvolvimento consolidar-se em um padrão estável.” (p. 11, v. 3).

O autor desenvolveu alguns estudos para avaliar os efeitos da privação da figura materna na vida adulta e concluiu que, dependendo da idade em que ocorre a privação, há prejuízos no desenvolvimento do raciocínio abstraio ou da personalidade. "As diferenças individuais nas reações de adultos à perda durante a infância dependem das circunstâncias dos acontecimentos e do momento mais ou menos crítico do desenvolvimento da criança” (p. 30, v. 3).

"Algumas descobertas sugerem que a privação da mãe pode ter efeitos particularmente negativos sobre determinados processos. Dentre os processos intelectuais, os mais vulneráveis parecem ser a linguagem e a abstração. Dentre os processos de personalidade, os mais vulneráveis parecem ser os que são subjacentes à capacidade de estabelecer e manter relações interpessoais profundas e significativas e à capacidade de controlar os impulsos em benefícios de objetivos de longo alcance”. (BOWLBY, 1981, p. 202).

“A privação após a idade de três ou quatro anos, (...) não tem os mesmos efeitos destrutivos sobre o desenvolvimento da personalidade e sobre a capacidade de raciocínio abstrato. Contudo, tem ainda como resultado uma necessidade excessiva de afeto e exagerados impulsos de vingança, que provocam um agudo conflito interno, infelicidade e atitudes sociais muito negativas. (...) A limitada noção de tempo da criança e sua tendência a interpretar mal uma situação contribuem muito para suas dificuldades. (...) Mesmo para uma criança de cinco ou seis anos, as semanas são terrivelmente longas e os meses são algo quase infindável. Esta noção muito restrita de tempo precisa ser compreendida para que possamos apreender totalmente o desespero que uma criança pequena sente por ser deixada sozinha num lugar estranho" (BOWLBY, 1981, p. 63-4).

De modo geral, a perda do cuidado materno pode gerar um adulto incapaz de confiar no outro. "Hoje é admitido que não apenas crianças, mas seres humanos de todas as idades são mais felizes e mais capazes de melhor exercitar seus talentos quando seguros de que, atrás de si, há uma ou mais pessoas em quem confiam e que lhes darão ajuda em caso de necessidade. A pessoa em quem se confia representa base segura para a ação.” (p. 375, v. 2).

$\mathrm{O}$ autor pondera que, embora haja diversos estudos que diferem quanto às fontes de observação e quanto aos quadros e modelos teóricos, "há forte concordância quanto a certos princípios básicos”. A autoconfiança e a capacidade de confiar nos outros "são produto de uma 
família que dá a seus filhos forte apoio, que lhes respeita as aspirações pessoais, o senso de responsabilidade e a capacidade de lidar com o mundo. Dessa forma, longe de comprometer a autoconfiança de uma criança, muito a estimulam a base segura e o forte apoio proporcionados pela família." (p. 378/v. 2).

BOWLBY (1981) refere que o adulto que sofreu privação na infância tende a reproduzir o tratamento que recebeu quando criança. "A assistência adequada às crianças privadas de uma vida familiar normal pode, agora, ser encarada como essencial para o bem estar mental e social da comunidade e não apenas como um aio de humanidade. Isto porque, quando esses cuidados são negligenciados, como ainda hoje ocorre em todos os países do mundo ocidental, elas crescem e reproduzem a própria privação. As crianças que sofrem privação, quer em seus lares quer fora deles, são uma fonte de contaminação social”. (p. 217).

Seu pensamento é coerente com a atual vertente de incluir os casos de maus-tratos e negligência como um problema de saúde pública. GUERRA, SANTORO \& AZEVEDO (1992) fazem referência a essa questão; além de defenderem a inclusão desses casos na saúde coletiva, sugerem o envolvimento de equipes multidisciplinares nos projetos de intervenção para assistir o binômio criança-família.

A adesão a essa vertente implica rever o conceito de família; do contrário, os projetos destinados a ela tendem ao fracasso. É preciso considerar como está constituída a família no Brasil, tendo em vista as diferenças sócio-econômicas e culturais, para daí se obter um diagnóstico real da criança em situação de rua e, a partir daí, estabelecer metas e elaborar projetos multidisciplinares com perspectivas de intervenção que gerem resultados mais eficazes e com maior impacto social.

GOMES (1994) faz referência à respeito dizendo que a política pública não pode ignorar as condições concretas das populações destinatárias. $\mathrm{E}$, ainda, atribui a todo cidadão a tarefa de descobrir um modo de ajudar as famílias mais pobres. Segundo a autora, “as famílias pobres não podem arcar por mais tempo, sós e desamparadas, com a responsabilidade da construção do futuro de seus filhos (...), do maior contingente das novas gerações brasileiras” (p. 60).

\section{CONSIDERAÇÕES FINAIS}

A identidade do "eu” é sempre construída na relação com o “outro”. Em se tratando de desenvolvimento infantil, a identidade da criança é formada principalmente na relação com sua família. Se esta for conceituada negativamente, a criança assimilará para si parte dessa identidade negativa.

Quando a criança recorre à rua por maus tratos, não está apenas fugindo da dor física; está tentando preservar sua integridade e sua auto-estima; está se afastando daquilo que a destrói e a humilha. Mas a vivência na rua, e mesmo em alguns abrigos, também não Ihe atribui identidade positiva; ao contrário, reforça e acentua a identidade negativa de "menino de rua" e, ainda, a identidade do porvir, a de suposto "futuro marginal”.

Desse modo, a criança em situação de rua parece não encontrar saída. Ela precisa estar inserida em uma família para sentir-se protegida de todo tipo de violência, seja esta fisica ou moral. Precisa pertencer a um grupo familiar que lhe dê perspectivas de um futuro promissor. Precisa acreditar que é bem-vinda na sua comunidade e na sociedade a qual pertence. Sem esses requisites, torna-se difícil reagir positivamente às exigências que a sociedade lhe impoe.

Segundo CIAMPONE (1998) “a família constitui a sede dos acontecimentos mais significativos na vida do indivíduo. Se a experiência familiar é negada ou de alguma forma desatendida, em função das condições concretas de vida e dos seus perfis, em função também dos processos de saúde e doença a que ela está submetida, o indivíduo estará mais predisposto a estados de confusão intrapsíquica, que podem levar ao desenvolvimento de condutas que variam numa gama muito grande entre o normal e o patológico”.

Assim, é importante a participação de profissionais de saúde nos programas (governamentais ou não) de reinserção da criança na família de origem ou substituta, nas realizações de pesquisas, no ensino de graduação e em eventos técnicos-científicos que conduzam a adesão de mais adeptos em defesa dessa causa. 


\begin{abstract}
This paper focuses on part of the data of the author's thesis about the trajectory of a group of school-aged street children who used to attend two public shelters in the city of Sao Paulo. The data, gathered by means of interviews, were analyzed according to the theories of Social Representation and Analysis of Contents, following BARDIN's and MINAYO's ideas. The thematic categories arising from the transcribed discourse were grouped into meaningful experiences for the children, among which we find "the family". The synthesis of the analyzed categories clearly showed that violence permeates the lives of those children, resulting in experiences that restrict their full development. The author identifies that the children run away from home when their family fails in giving them protection and love. The author concludes that the solution depends on the implementation of social and health policies, directed mainly to the child-family in risk situation.
\end{abstract}

Key-words: street children; family; violence; school health.

\section{REFERÊNCIAS BIBLIOGRÁFICAS}

BARDIN, L. Análise de conteúdo. Lisboa: Edições 70, 1979.

BOWLBY, J. Cuidados materrnos e saúde mental. São Paulo, Martins Fontes, 1981.

BOWLBY, J. Apego. $2^{\text {a }}$ ed. São Paulo: Martins Fontes, 1990. v. 1.

BOWLBY, J. Separação: angústia e raiva. $2^{\mathrm{a}}$ ed. São Paulo, Martins Fontes, 1993. v. 2.

BOWLBY, J. Perda: tristeza e depressão. São Paulo, Martins Fontes, 1993. v. 3.

BRASIL. Ministério da Saúde. Conselho Nacional de Saúde. Resolução n 196/96 sobre pesquisa envolvendo seres humanos. Brasília, 1996.

CIAMPONE, M. H. T. Uma proposta de intervenção baseada na família. In: SILVA, L.A.P.; STANISCI, S. A.; BACCHETTO, S. (Orgs.). Familias: aspectos conceituais e questões metodológicas em projetos. Brasília / São Paulo: MPAS-SAS FUNDAP, 1998. p. 23-30.
GOMES, J. V. Socialização primária: tarefa familiar? Cadernos de Pesquisa, 91: 54-61, 1994.

GUERRA, V. N.d. A.; SANTORO Jr, M.; AZEVEDO, M. A. Violência doméstica contra crianças e adolescentes e políticas de atendimento: do silêncio ao compromisso. Revista Brasileira Crescimento Desenvolvimento $\mathrm{Hu}-$ mano, 2(1): 71-96, 1992.

JOVCHELOVITCH, S. Representações sociais: para uma fenomenologia dos saberes sociais. Psicologia \& Sociedade, 10(1): 54-68, 1998.

MINAYO, M.C.d.S. O desafio do conhecimento: pesquisa qualitativa em saúde. $2^{a}$ ed. São Paulo/Rio de Janeiro: Hucitec/Abrasco, 1993.

SPINK, M. J. (Org.), O conhecimento no cotidiano: as representações sociais na perspectiva da psicologia social. São Paulo, Brasiliense, 1993.

Recebido em 20/06/2001

Modificado vem 05/08/2001

Aprovado em 12/08/2001 